\title{
Sunflower Protein Concentrates and Isolates Prepared from Oil Cakes Have High Water Solubility and Antioxidant Capacity
}

\author{
Pablo R. Salgado • Sara E. Molina Ortiz • \\ Silvana Petruccelli $\cdot$ Adriana N. Mauri
}

Received: 6 March 2010/Revised: 6 August 2010/ Accepted: 24 August 2010/Published online: 8 September 2010

(C) AOCS 2010

\begin{abstract}
Increasing the applications of industrial byproducts is of great interest. Therefore, in the present study, sunflower oil cake from a local oil manufacturing company was used to obtain soluble protein concentrates and isolates with different content of phenolic compounds. All the extraction procedures evaluated resulted in concentrates and isolates with water solubility higher than $75 \%$ but with different chemical composition, color and physicochemical properties (i.e. surface hydrophobicity, thermal stability, and polypeptide composition). Since no extraction process led to a complete extraction of phenolic compounds, all the products exhibited antioxidant activity, which depended on the concentration of such compounds. Phenolic compounds give a dark color to sunflower protein concentrates and isolates; nevertheless their final color tone was more dependent on the conditions used in the preparation process than on the amount of phenolic compounds in the product. The results demonstrate the value of sunflower industrial oil cake as a source of proteins with high water solubility, good physicochemical properties and antioxidant activity.
\end{abstract}

Keywords Sunflower oil cake $\cdot$ Sunflower protein isolates · Phenolic compounds · Protein solubility · Antioxidant properties - Physicochemical properties

P. R. Salgado $\cdot$ S. E. Molina Ortiz $\cdot$ S. Petruccelli

A. N. Mauri $(\bowtie)$

Centro de Investigación y Desarrollo en Criotecnología

de Alimentos (CIDCA-CCT La Plata- CONICET),

Facultad de Ciencias Exactas,

Universidad Nacional de La Plata (UNLP),

Calle 47 y 116 S/N , B1900AJJ La Plata,

Buenos Aires, Argentina

e-mail: anmauri@quimica.unlp.edu.ar

\section{Introduction}

Defatted flours, a by-product of the oil industry, constitute an important source of proteins. In general, the industrial process of oil extraction leads to denaturation and diminished solubility of proteins [1,2], thus affecting the yield of protein extraction and its economical benefit.

In 2009, Argentina was the second largest sunflower oil producer in the world and the largest exporter of sunflower refined oil and oil cake [3]. Among sunflower oil manufacturing by-products, the sunflower oil cake is underused, being almost exclusively employed for animal feeding in spite of its high content of highly digestible proteins with an important content of essential amino acids (except for lysine and sulfur amino acids) [2]. The high concentration of phenolic compounds, of which the majority is chlorogenic acid with small amounts of caffeic acid $[2,4,5]$, is the main reason for the underutilization of sunflower oil cake. In addition, these compounds reduce protein solubility and cause unwanted organoleptic characteristics $[2,4,5]$. Thus, different methods to remove phenolic compounds have been proposed, among them extraction with aqueous alcoholic solutions which has been shown to be very effective [4-6]. In parallel, however, in the last few years there has been increasing interest in keeping these phenolic compounds, and even in adding them to the formulations, due to their antioxidant activity [7] and their benefits for preventing diseases and delaying aging [8]. In this context, it is unclear whether these compounds should be removed or not when protein concentrates and isolates are prepared from the sunflower oil cake.

The aims of this study were: (1) to develop methods for obtaining, from the residual pellet of the local oil industry, sunflower protein concentrates and isolates with different contents of phenolic compounds, and (2) to assess the 
effect of such compounds on the structural and physicochemical properties (particularly water solubility of the proteins and surface hydrophobicity) and the antioxidant capacity of the products.

\section{Materials and Methods}

Materials

Defatted sunflower (Helianthus annuus L.) oil cake was provided by Aceitera Santa Clara (Molinos Río de La Plata, Rosario, Argentina). This starting material was ground in a mill (Bühler Miag MLGV Variostuhl), and passed through a screen with a particle diameter of $1.19 \mathrm{~mm}$, thus yielding the "milled sunflower oil cake".

Preparation of Sunflower Protein Concentrates and Isolates

\section{Preparation of Sunflower Protein Concentrates}

Aqueous dispersions of the milled sunflower oil cake (1:10 $\mathrm{w} / \mathrm{v}$ ) were stirred for $1 \mathrm{~h}$ and the $\mathrm{pH}$ was adjusted to 9 with $2 \mathrm{~N} \mathrm{NaOH}$. The dispersion was centrifuged at $30,000 \times g$ (Avanti J-25, Beckman Coulter, CA, USA) at $20{ }^{\circ} \mathrm{C}$ for $15 \mathrm{~min}$, and the supernatant was collected. The precipitate was subjected to a second extraction of proteins as described before. The supernatants of both extractions were pooled, the $\mathrm{pH}$ was adjusted to 9 , and the mixture was frozen at $-80{ }^{\circ} \mathrm{C}$ before freeze-drying (Heto FD4 lyophilizer, connected to a Vacuubrand RZ 5 vacuum pump).
This resulted in a sunflower protein concentrate (C) (see Table 1). Three replicates of $\mathrm{C}$ were prepared.

\section{Phenolic Compounds Extraction}

To obtain sunflower protein concentrates with lower phenolic content, the milled sunflower oil cake was subjected to serial washes at acidic $\mathrm{pH}$ before extracting the proteins in an alkaline medium. The milled sunflower oil cake was suspended in the extraction buffer (1:15 w/v ratio), the $\mathrm{pH}$ was adjusted to 5 , and the suspension was stirred $30 \mathrm{~min}$ (with verification of $\mathrm{pH}$ constancy every $10 \mathrm{~min}$ ). The mixture was centrifuged at $30,000 \times g$ for $15 \mathrm{~min}$ at $20^{\circ} \mathrm{C}$ (Avanti J-25 Beckman Coulter, CA, USA), and the precipitate obtained was subjected to a new extraction of phenolic compounds under the same conditions. After four extractions, the residual pellet was subjected to protein extraction at alkaline $\mathrm{pH}$ as described for the preparation of $\mathrm{C}$ product. The media used for extracting phenolic compounds were as follows: water; $0.1 \% \mathrm{w} / \mathrm{v} \mathrm{Na}_{2} \mathrm{SO}_{3}$ solution; $70 \% \mathrm{v} / \mathrm{v}$ ethanol; $80 \% \mathrm{v} / \mathrm{v}$ methanol; $92: 8 \mathrm{v} / \mathrm{v}$ 1-buthanol in $0.005 \mathrm{~N} \mathrm{HCl}$ (buthanol). The protein concentrates obtained with these media were designated $\mathrm{CW}, \mathrm{CS}, \mathrm{CE}, \mathrm{CM}$ and $\mathrm{CB}$, respectively (see Table 1). Three replicates of CW and $\mathrm{CS}$, and two replicates of $\mathrm{CE}, \mathrm{CM}$ and $\mathrm{CB}$, were prepared.

\section{Preparation of Sunflower Protein Isolates}

The milled sunflower oil cake was processed as described for protein concentrates $(1: 10 \mathrm{w} / \mathrm{v})$, but the supernatants obtained after the protein extraction steps were mixed and subjected to isoelectric precipitation by adjusting the $\mathrm{pH}$ to
Table 1 Summary of the procedures used for preparing sunflower protein concentrates and isolates

\footnotetext{
$\times$, step performed; -, step not performed

a Extraction solvent used

b Drying by lyophilization
}

\begin{tabular}{|c|c|c|c|c|c|}
\hline Sample & 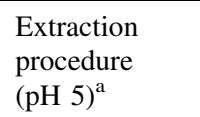 & $\begin{array}{l}\text { Extraction } \\
\text { of proteins } \\
(\mathrm{pH} \mathrm{9)}\end{array}$ & $\begin{array}{l}\text { Isoelectric } \\
\text { precipitation } \\
(\mathrm{pH} \mathrm{4.5)}\end{array}$ & $\begin{array}{l}\text { Resuspension } \\
(\mathrm{pH} 9)\end{array}$ & Drying $^{b}$ \\
\hline $\mathrm{C}$ & - & $x$ & - & - & $x$ \\
\hline $\mathrm{CW}$ & Water & $x$ & - & - & $x$ \\
\hline CS & $0.1 \% \mathrm{Na}_{2} \mathrm{SO}_{3}$ & $x$ & - & - & $x$ \\
\hline $\mathrm{CE}$ & Ethanol $70 \%$ & $\times$ & - & - & $x$ \\
\hline $\mathrm{CM}$ & Methanol $80 \%$ & $x$ & - & - & $x$ \\
\hline CB & Acidic butanol & $x$ & - & - & $x$ \\
\hline I & - & $x$ & $x$ & $x$ & $\times$ \\
\hline IW & Water & $x$ & $x$ & $x$ & $x$ \\
\hline IS & $0.1 \% \mathrm{Na}_{2} \mathrm{SO}_{3}$ & $x$ & $x$ & $\times$ & $\times$ \\
\hline
\end{tabular}


4.5 with $2 \mathrm{~N} \mathrm{HCl}$. The mixture was stirred for $30 \mathrm{~min}$ and then centrifuged at $30,000 \times g$ for $15 \mathrm{~min}$ at $4{ }^{\circ} \mathrm{C}$ (Avanti J-25, Beckman Coulter, CA, USA). The resulting precipitate was washed with distilled water at $\mathrm{pH} 4.5$ and centrifuged once more. This second precipitate was resuspended in water (up to approximately $10 \% \mathrm{w} / \mathrm{v}$ ) and adjusted to $\mathrm{pH} 9$ with $2 \mathrm{~N} \mathrm{NaOH}$. The suspension was stirred for $15 \mathrm{~min}$, frozen at $-80{ }^{\circ} \mathrm{C}$, and finally freezedried (Heto FD4 lyophilizer, connected to a Vacuubrand RZ 5 vacuum pump). This product was designated I. The IW and IS products were obtained by adding four serial washing steps with water or $0.1 \%$ w/v $\mathrm{Na}_{2} \mathrm{SO}_{3}$ before the protein isolation procedure (see Table 1). Three replicates of each protein isolate (I, IW and IS) were prepared.

\section{Procedures Yields}

The protein recovery yields ( $g$ of proteins in the product/g of proteins in the milled oil cake) and the percent residual content of phenolic compounds (mg of phenolic compounds in the product/mg of phenolic compounds in the milled oil cake) were determined for each procedure assayed.

\section{Chemical Composition Determination}

The chemical composition of the milled sunflower oil cake and the protein concentrates and isolates obtained were determined. Moisture and ash values were determined by gravimetric measure (AOAC 935.29 and AOAC 923.03, respectively [9]). The protein content was determined by the Kjeldahl method (AOAC 920.53 [9]) using 5.55 as nitrogen-to-proteins conversion factor. The lipid content of the milled sunflower oil cake was determined by Soxhlet (AOAC 920.39 [9]) using $n$-hexane as the extraction solvent, and the carbohydrate content was determined by the Felhing-Causse-Bonnans method (AOAC 14023/24 [9]) after a 2 h hydrolysis in strong acid medium, using a $0.5 \%$ $\mathrm{w} / \mathrm{v}$ glucose solution in water as standard. The percent content of fiber was calculated by difference. Phenolic compounds were measured by UV spectrophotometry at $324 \mathrm{~nm}$ as described by Moore et al. [10], using chlorogenic acid (CGA, Chemika Fluka, Germany) as the standard, and by RP-HPLC as described González-Pérez et al. [6], using CGA and caffeic acid (Sigma-Aldrich Chemical Co., CA, USA) as the standards. All determinations were performed at least in duplicate for each replicate.

\section{Anti-Nutritional Factors Determination}

The urease and anti-trypsin activities were measured in the milled sunflower oil cake and also in thermally untreated flour prepared from wet soy seeds, which was used as a positive control.

\section{Urease Activity Determination}

The residual urease activity of the products against urea in solution was determined by the AOCS method Ba 9-59 (1995) [11]. Samples (200 mg) were dispersed in $10 \mathrm{ml}$ of $0.1 \mathrm{M}$ sodium phosphate buffer containing $3 \% \mathrm{w} / \mathrm{v}$ urea (Riedel-de Haën, Germany) at $\mathrm{pH}$ 7. The mixture was incubated at $30{ }^{\circ} \mathrm{C}$ for $30 \mathrm{~min}$ before $\mathrm{pH}$ measurement. A blank tube without urea was processed in parallel under the same conditions. The residual urease activity was determined as the $\mathrm{pH}$ difference between the sample and the blank at 30 min of reaction $(\Delta \mathrm{pH})$. This determination was done in triplicate for each replicate.

\section{Anti-Tryptic Activity Determination}

Anti-tryptic activity was measured according to the AOCS protocol Ba 1275 (1995) [11]. The assay is based on the inhibition of trypsin activity, using the synthetic substrate $N$-benzoyl-DL-arginine- $p$-nitroanilide hydrochloride (BAPNA, Sigma-Aldrich Inc., St. Louis, USA) that is hydrolyzed by trypsin releasing the yellow product nitroanilide.

\section{Sample Preparation}

A sample $(1 \mathrm{~g})$ was mixed with $50 \mathrm{ml}$ of $0.01 \mathrm{~N} \mathrm{NaOH}$ and incubated with agitation for $3 \mathrm{~h}$ at room temperature. Aliquots of the extract were centrifuged $(23,700 \times \mathrm{g}, 10 \mathrm{~min}$ at $20{ }^{\circ} \mathrm{C}$ ) (Avanti J-25, Beckman Coulter, CA, USA) and supernatants were collected. Samples: supernatants (400 $\mu$, $1 \mathrm{mg}$ protein $/ \mathrm{ml}$ ) were mixed with $400 \mu$ l of trypsin (20 ppm trypsin in $1 \mathrm{mM} \mathrm{HCl,} \mathrm{Sigma-Aldrich} \mathrm{Inc.,} \mathrm{St.} \mathrm{Louis,} \mathrm{USA),}$ and $1 \mathrm{ml}$ of substrate (40 ppm BAPNA in $50 \mathrm{mM}$ Tris $25 \mathrm{mM} \mathrm{CaCl}_{2}$ buffer, $\mathrm{pH}$ 8.2) was added. The mixture was incubated at $37{ }^{\circ} \mathrm{C}$ with occasional agitation. At $10 \mathrm{~min}$, $200 \mu \mathrm{l}$ of acetic acid ( $30 \% \mathrm{v} / \mathrm{v}$ acetic acid) were added to stop the enzymatic reaction, and the absorbance $\left(\mathrm{Abs}_{\mathrm{s}}\right)$ at $410 \mathrm{~nm}$ was measured. Sample blank: supernatants $(400 \mu \mathrm{l} ; 1 \mathrm{mg}$ protein $/ \mathrm{ml}$ ) were mixed with $1 \mathrm{ml}$ of substrate and incubated for $10 \mathrm{~min}$ at $37{ }^{\circ} \mathrm{C}$ before adding $200 \mu \mathrm{l}$ of acetic acid and $400 \mu \mathrm{l}$ of trypsin. The absorbance $\left(\mathrm{Abs}_{\mathrm{bs}}\right)$ at $410 \mathrm{~nm}$ was measured. The residual trypsin activity $\left(\mathrm{Abs}_{\mathrm{rT}}\right)$ was calculated as the difference between $\mathrm{Abs}_{\mathrm{s}}$ and $\mathrm{Abs}_{\mathrm{bs}}$.

\section{Total Trypsin Activity}

$\mathrm{NaOH}(0.01 \mathrm{~N} ; 400 \mu \mathrm{l})$ was mixed with $400 \mu \mathrm{l}$ of trypsin and $1 \mathrm{ml}$ of substrate, and the mixture was incubated for $10 \mathrm{~min}$ at $37{ }^{\circ} \mathrm{C}$ before adding $200 \mu \mathrm{l}$ of acetic acid. The absorbance $\left(\mathrm{Abs}_{\mathrm{TA}}\right)$ at $410 \mathrm{~nm}$ was measured. The antitrypsin activity (ATA) was expressed as the difference between maximal and residual absorbances $\left(\mathrm{Abs}_{\mathrm{TA}}-\right.$ $\left.\mathrm{Abs}_{\mathrm{rT}}\right)$ at $10 \mathrm{~min}$ of enzymatic reaction in the assay 
conditions described. Determinations were done in quadruplicate for each replicate.

\section{Color}

Color of sunflower protein concentrates and isolates were determined using a Minolta Chroma meter (CR 300, Minolta Chroma Co., Osaka, Japan). A CIE Lab color scale was used to measure the degree of lightness $(L)$, redness $(+a)$ or greenness $(-a)$, and yellowness $(+b)$ or blueness $(-b)$ of the samples. The instrument was standardized using a white calibration plate $\left(L_{\text {standard }}=97.3, a_{\text {standard }}=0.14\right.$ and $b_{\text {standard }}=1.71$ ). To measure color parameters, protein samples were homogeneously dispersed on the white plate surface. Total color difference $(\Delta E)$ was calculated using the Equation 1:

$$
\begin{aligned}
& \Delta E \\
& =\sqrt{\left(L_{\text {sample }}-L_{\text {standard }}\right)^{2}+\left(a_{\text {sample }}-a_{\text {standard }}\right)^{2}+\left(b_{\text {sample }}-b_{\text {standard }}\right)^{2}}
\end{aligned}
$$

Values were expressed as the means of nine measurements on different areas of each sample for each replicate.

\section{Differential Scanning Calorimetry (DSC)}

A TA Instrument DSC Q100 V9.8 Build 296 (New Castle, DE, USA) was used for these studies. Temperature and heat flow calibration of the equipment was carried out according to ASTM standards, using lauric and stearic acid and indium as standards, respectively. Hermetically sealed aluminum pans containing $10-15 \mathrm{mg}$ of samples $(20 \% \mathrm{w} / \mathrm{v}$ of protein) were prepared and scanned at $10{ }^{\circ} \mathrm{C} / \mathrm{min}$ over the range of $20-120{ }^{\circ} \mathrm{C}$. Denaturation enthalpies $(\Delta H)$ and peak temperatures $\left(T_{\mathrm{d}}\right.$ in $\left.{ }^{\circ} \mathrm{C}\right)$ were taken from the corresponding thermograms (Universal Analysis V4.2E, TA Instruments, New Castle, DE, USA). Enthalpy values $(\Delta H)$ were expressed as $\mathrm{J} / \mathrm{g}$ protein, taking into account the dry weight (determined by perforating the pans and heating overnight at $105^{\circ} \mathrm{C}$ ) and the protein content of sample [12]. All assays were conducted in duplicate for each replicate.

Sodium Dodecyl Sulfate Polyacrylamide Gel Electrophoresis

The polypeptide composition of the milled sunflower oil cake and protein samples were analyzed by sodium dodecyl sulfate polyacrylamide gel electrophoresis (SDS-PAGE) using a separating gel $(12 \% \mathrm{w} / \mathrm{v}$ in polyacrylamide) with a stacking gel (4\% w/v in polyacrylamide) in a minislabs system (Bio-Rad Mini-Protean II Model) [13]. Protein molecular weights were estimated using low MW markers (Pharmacia, Amersham, England) that included phosphorylase b $(94,000)$, albumin $(67,000)$, ovalbumin $(43,000)$, carbonic anhydrase $(30,000)$, trypsin inhibitor $(20,100)$, and $\alpha$-lactalbumin $(14,400)$. Gel images were analyzed with the Image $\mathbf{J}$ software (US National Institute of Health, Bethesda, MD, USA).

\section{Protein Solubility in Water}

Samples were dispersed $(1 \mathrm{mg} / \mathrm{ml})$ in distilled water for $30 \mathrm{~min}$ with agitation, then the $\mathrm{pH}$ of the mixture was adjusted to 8 with $1 \mathrm{~N} \mathrm{NaOH}$ and the dispersion was kept, with constant agitation, for a further $1 \mathrm{~h} \mathrm{[14]}$. The dispersion was centrifuged at $23,700 \times g$ for $15 \mathrm{~min}$ at $20^{\circ} \mathrm{C}$ (Avanti J-25, Beckman Coulter, CA, USA). Soluble proteins were determined in the supernatant by the Bradford method [15] using bovine serum albumin (BSA, SigmaAldrich Chemical Co., St. Louis, USA) as standard. Results were expressed as percentage of the original protein content in the starting material. Determinations were performed at least in duplicate for each replicate.

\section{Surface Hydrophobicity}

Sunflower protein concentrates and isolates were dissolved in water $(5 \mathrm{mg} / \mathrm{mL}, \mathrm{pH} 8)$ with occasional stirring for $1 \mathrm{~h}$ at $20{ }^{\circ} \mathrm{C}$ and then centrifuged at $23,700 \times g$ for $15 \mathrm{~min}$ at $20^{\circ} \mathrm{C}$. Serial dilutions were made with water at concentrations in the $0.05-5 \mathrm{mg} / \mathrm{mL}$ range. Then the surface hydrophobicity (Ho) was determined according to the method described by Kato and Nakai [16] using 8-aniline-1-naphthalene sulfonate (ANS, Aldrich Chemical Company, Inc., USA) $8 \mathrm{mM}$ as probe $\left(\lambda_{\text {excitation }}=364 \mathrm{~nm}\right.$ and $\lambda_{\text {emission }}=475 \mathrm{~nm}$, using a digital fluorimeter, Perkin-Elmer model 2000, Norwalk, CT, USA). Protein concentration was determined according to the method of Bradford [15]. All determinations were performed in duplicate for each replicate.

\section{Antioxidant Capacity}

The $\mathrm{ABTS}^{+}$radical (2,2-azinobis-(3-ethylbenzothiazoline6-sulfonic acid)) scavenging capacity by antioxidant compounds was determined according to the method described by Re et al. [17] with minor modifications. To this end, the radical $\mathrm{ABTS}^{+}$was generated by oxidation of $7 \mathrm{mM}$ ABTS (Fluka, Sigma-Aldrich, with $2.45 \mathrm{mM}$ potassium persulfate (Anedra, Argentina) and kept in the dark at room temperature for 12-16 h. An aliquot of the stock solution was diluted with distilled water in order to prepare the working solution of $\mathrm{ABTS}^{+}$radical with absorbance of $0.70 \pm 0.03$ at $734 \mathrm{~nm}$. Protein concentrates and isolates dissolved in sodium phosphate buffer $0.01 \mathrm{M}$, pH 7.4 $(1 \mathrm{mg}$ protein $/ \mathrm{ml}, 50 \mu \mathrm{l})$ were added to $950 \mu \mathrm{l}$ of the solution containing the $\mathrm{ABTS}^{+}$The mixture was vortexed 
for $1 \mathrm{~min}$ and its absorbance at $734 \mathrm{~nm}\left(\mathrm{Abs}_{\mathrm{s}}\right)$ was measured $10 \mathrm{~min}$ after the addition of the pre-formed radical. $\mathrm{ABTS}^{+}$is reduced in the presence of hydrogen-donating compounds with the concomitant decrease in the absorbance at $734 \mathrm{~nm}$. The reaction blank $\left(\mathrm{Abs}_{\mathrm{rb}}\right)$ was obtained using the same procedure using $50 \mu$ of sodium phosphate buffer instead of protein solution. The antioxidant capacity (AC) was calculated with Eq. 2. All determinations were performed at least in triplicate for each replicate.

$\mathrm{AC}=\frac{A b s_{\mathrm{rb}}-A b s_{\mathrm{s}}}{A b s_{\mathrm{rb}}} \cdot 100$

\section{Statistical Analysis}

Results were expressed as means \pm standard deviation and were analyzed by analysis of variance (ANOVA). Means were tested with the Fisher's least significant difference test for paired comparison, with a significance level $\alpha=0.05$, using the Statgraphics Plus version 5.1 software (Statgraphics, USA).

\section{Results and Discussion}

\section{Characterization of the Milled Sunflower Oil Cake}

The milled sunflower oil cake used had a minimal content of lipids (less than 1\%) due to the industrial procedure for oil extraction, but presented a high content of proteins $(31.7 \% \pm 0.1)$ and carbohydrates $(23.2 \% \pm 0.9)$. It also contained a high percentage of salts $(8.0 \% \pm 0.4)$ and fibers $(33.6 \% \pm 2.3)$, the later due to the presence of husk remnants. The detailed percent chemical composition is similar to that reported in studies on similar products [1820]. A particular characteristic of the sunflower oil cake, as compared to other sources of vegetable proteins (e.g. soy) was its high content of phenolic compounds $(2.7 \% \pm 0.1)$, mainly chlorogenic acid (75\%) and caffeic acid (19\%). The total content of phenolic compounds in the sunflower oil cake falls within the range reported for similar raw materials (1.5-5.8\%) and agrees with the phenolic profiles previously reported $[2,4]$. The DSC thermogram of the milled sunflower pellet, not shown, presented a single protein denaturation endotherm at $100.6^{\circ} \mathrm{C}$ with a denaturation enthalpy of $9.4 \mathrm{~J} / \mathrm{g}$ of protein. González-Pérez et al. [6] reported an enthalpy value of $14.5 \mathrm{~J} / \mathrm{g}$ of protein for a sunflower native protein isolate. Thus, it can be concluded that the high temperatures $\left(150-170{ }^{\circ} \mathrm{C}\right)$, pressures $\left(50 \mathrm{~kg} / \mathrm{m}^{2}\right)$, and organic solvent ( $n$-hexane) treatments used in the process that generated the oil cake, allowed the sunflower proteins to remain in a partially native state. Notably, in spite of this thermal stability, no urease activity was found in the sunflower oil cake
$(\Delta \mathrm{pH}=0.00 \pm 0.01)$ and the same was true for antitrypsin activity $(\mathrm{ATA}=0.01 \pm 0.01)$. The positive control for both determinations was a flour prepared from wet soy seeds without thermal treatment, for which the corresponding values were $\Delta \mathrm{pH}=2.41 \pm 0.01$ and $\mathrm{ATA}=$ $1.18 \pm 0.04$, respectively. It is also important to note that the published information about the presence in sunflower of anti-nutritional factors, such as protease inhibitors, is conflicting. While these compounds were not detected in sunflower seeds in some studies [4], others have reported the presence of an anti-tryptic factor in seeds from sunflower varieties less sensitive to sclerotin [21].

Chemical Composition of Sunflower Protein

Concentrates and Isolates

In order to obtain soluble protein concentrates and isolates from sunflower oil cake different procedures were used including extraction procedures with different solvents to eliminate phenolic compounds and/or isoelectric precipitation after protein extraction. The procedures tested in this work and the nomenclature for the protein concentrates and isolates are summarized in Table 1. In addition, the chemical composition of the sunflower protein concentrates and isolates obtained using these procedures, the protein yields and the efficacy of removal of phenolic compounds are presented in Table 2. The highest protein yield $(\approx 46 \%)$ was obtained for $\mathrm{C}$ product, which is also the one with lowest protein content, the highest amount of phenolic compounds and salts. The addition of successive extraction steps to eliminate phenolic compounds led to an increase in the protein content in the concentrates, which was more marked in products obtained by extraction with water $(\mathrm{CW})$ or $\mathrm{Na}_{2} \mathrm{SO}_{3}$ (CS). These products were characterized by significantly lower contents of phenolic compounds, as well as lower contents of salts as compared to $\mathrm{C}$, due to the solubilization of these components in the aqueous extraction media. While the use of aqueous alcoholic solutions permitted a higher reduction of phenolic compounds comparable to that attained with the use of sodium sulfite, the extraction procedures with alcohol were less efficient for the extraction of other components that solubilize more easily in water, such as salts, carbohydrates and fibers. Thus, the protein contents of $\mathrm{CE}, \mathrm{CM}$ and $\mathrm{CB}$ concentrates were intermediate between those of $\mathrm{C}$ and $\mathrm{CW}$ or $\mathrm{CS}$, with the protein yields of the procedures used for these products around 20-25\%. In addition, CE, CM and CB were the ones with the highest moisture content $(\approx 10 \%)$, possibly due to their higher retention of salts and carbohydrates, which can bind water.

Regarding the protein isolates, sample I had the lowest protein content ( $72 \%$ dry basis) and the highest contents of 
phenolic compounds and other components such as carbohydrates, fibers and lipids (Table 2). Additional steps for removing phenolic compounds using aqueous extraction procedures produced isolates of higher protein content (76-78\% dry basis) and lower levels of phenolic compounds, without significant differences in salt and moisture content. As expected, protein isolates had higher protein content and lower salt and moisture content than their corresponding concentrates.

Phenolic compounds content differences were lower for the other samples (CW-IW and CS-IS) because the extraction procedures performed to remove the phenolic compounds produced the same concentration effect than the one produced by the isoelectric precipitation. The analysis of alcoholic concentrates in particular shows that extraction procedures only increased the removal of phenolic compounds by $1-5 \%$ as compared to aqueous extraction procedures, but led to lower protein yields (20-25\%). In every case the reduction of protein yield can be attributed to the solubilization of these components in the extraction solvent (in the aqueous media) or to a diminished solubility due to aggregation (in the alcoholic media) [22]. None of the procedures assayed resulted in the complete removal of phenolic compounds, indicating that the residual fraction might be interacting with proteins. This interaction was confirmed by RP-HPLC separation and detection at $324 \mathrm{~nm}$ (for phenolic compounds) and at $280 \mathrm{~nm}$ (for proteins) (Fig. 1). Free CGA and CA had retention times (15.1 and $18.3 \mathrm{~min}$, respectively) different from those associated with proteins (27-32 min, labeled as "II"). Minor unidentified phenolic compounds or CGA isomers (4 and $8 \mathrm{~min}$, labeled as "I") [23] are also present in the samples.

\section{Color}

Sunflower protein concentrates and isolates obtained had color that was dependent of the content of phenolic compounds and the extraction procedures employed. Table 3 shows the Hunter Lab color parameters and the color difference $(\Delta E)$ of the products. Samples $C$ and I had a greenish color (negative $a$ values), which can be attributed to the oxidation of phenolic compounds to o-quinones during protein extraction in an alkaline medium $[24,25]$. Protein products subjected to extraction of phenolic compounds with water or sodium sulfite had a lighter tone (higher $L$ values) and a more brownish color as evidenced by higher values of $a$ and $b$ parameters (Table 3 ). On the other hand, CS and IS products had the lowest color levels (lowest $\Delta E$ ). This can be attributed to reductive environment generated by sulfite that protect phenolic compounds from the oxygen of the air.

The content of phenolic compounds is not the only factor that determines the color of the protein concentrates or isolates. Alkaline treatment prior removal of phenolic compounds induces a greenish color that cannot be

Table 2 Chemical composition of the sunflower oil cake, protein concentrates and isolates

\begin{tabular}{|c|c|c|c|c|c|c|c|}
\hline \multirow[t]{2}{*}{ Sample } & \multicolumn{5}{|c|}{ Chemical composition (\%) } & \multicolumn{2}{|l|}{ Yields $(\%)^{* * *}$} \\
\hline & Proteins ${ }^{*}$ & $\begin{array}{l}\text { Phenolic } \\
\text { compounds }\end{array}$ & Ashes $^{*}$ & Moisture & Others $^{*, * *}$ & $\begin{array}{l}\text { Proteins } \\
\text { recovery }\end{array}$ & $\begin{array}{l}\text { Phenols } \\
\text { elimination }\end{array}$ \\
\hline Oil cake & $31.7 \pm 0.1^{\mathrm{a}}$ & $2.7 \pm 0.1^{\mathrm{d}}$ & $8.0 \pm 0.4^{\mathrm{d}}$ & $11.0 \pm 0,9^{\mathrm{f}}$ & 57.6 & - & - \\
\hline \multicolumn{8}{|c|}{ Concentrates } \\
\hline $\mathrm{C}$ & $46.6 \pm 0.4^{\mathrm{b}}$ & $6.0 \pm 0.2^{\mathrm{e}}$ & $9.1 \pm 0.4^{\mathrm{e}}$ & $6.8 \pm 0.1^{\mathrm{c}}$ & 38.3 & $46.1 \pm 0.6^{\mathrm{h}}$ & $29.4 \pm 3.9^{\mathrm{a}}$ \\
\hline CW & $75.5 \pm 0.8^{\mathrm{g}}$ & $2.0 \pm 0.2^{\mathrm{c}}$ & $5.0 \pm 0.4^{\mathrm{b}}$ & $8.1 \pm 0.1^{\mathrm{d}}$ & 17.5 & $35.2 \pm 0.5^{\mathrm{f}}$ & $88.9 \pm 1.3^{\mathrm{b}}$ \\
\hline CS & $71.4 \pm 0.6^{\mathrm{e}}$ & $1.4 \pm 0.1^{\mathrm{a}}$ & $6.4 \pm 0.2^{\mathrm{c}}$ & $5.4 \pm 0.3^{\mathrm{b}}$ & 20.8 & $34.8 \pm 1.0^{\mathrm{f}}$ & $91.8 \pm 0.4^{\mathrm{b}, \mathrm{c}, \mathrm{c}}$ \\
\hline CE & $63.2 \pm 0.1^{\mathrm{d}}$ & $1.4 \pm 0.1^{\mathrm{a}}$ & $10.0 \pm 0.9^{\mathrm{e}}$ & $9.4 \pm 0.7^{\mathrm{e}}$ & 25.4 & $25.2 \pm 0.1^{\mathrm{c}}$ & $93.3 \pm 0.7^{\mathrm{d}}$ \\
\hline $\mathrm{CM}$ & $59.8 \pm 0.1^{\mathrm{c}}$ & $1.5 \pm 0.1^{\mathrm{a}, \mathrm{b}}$ & $12.5 \pm 0.5^{\mathrm{f}}$ & $10.9 \pm 0.8^{\mathrm{f}}$ & 26.2 & $22.1 \pm 0.1^{\mathrm{b}}$ & $93.6 \pm 0.5^{\mathrm{d}}$ \\
\hline $\mathrm{CB}$ & $59.3 \pm 0.1^{\mathrm{c}}$ & $1.5 \pm 0.1^{\mathrm{a}, \mathrm{b}}$ & $12.2 \pm 0.4^{\mathrm{f}}$ & $10.0 \pm 0.7^{\mathrm{e}, \mathrm{f}}$ & 27.1 & $19.9 \pm 0.1^{\mathrm{a}}$ & $94.1 \pm 0.3^{\mathrm{d}}$ \\
\hline \multicolumn{8}{|l|}{ Isolates } \\
\hline I & $72.4 \pm 0.5^{\mathrm{f}}$ & $1.7 \pm 0.5^{\mathrm{b}}$ & $3.5 \pm 0.1^{\mathrm{a}}$ & $3.3 \pm 1.0^{\mathrm{a}}$ & 22.4 & $36.5 \pm 0.3^{\mathrm{g}}$ & $89.8 \pm 1.0^{\mathrm{b}, \mathrm{c}}$ \\
\hline IW & $78.8 \pm 0.2^{\mathrm{i}}$ & $1.6 \pm 0.1^{\mathrm{a}, \mathrm{b}}$ & $2.7 \pm 0.1^{\mathrm{a}}$ & $3.0 \pm 0.1^{\mathrm{a}}$ & 16.9 & $29.1 \pm 0.1^{\mathrm{d}}$ & $92.9 \pm 0.8^{\mathrm{c}, \mathrm{d}}$ \\
\hline IS & $76.5 \pm 0.3^{\mathrm{h}}$ & $1.4 \pm 0.1^{\mathrm{a}}$ & $3.1 \pm 0.1^{\mathrm{a}}$ & $2.8 \pm 0.1^{\mathrm{a}}$ & 19.0 & $32.4 \pm 0.2^{\mathrm{e}}$ & $92.9 \pm 1.1^{\mathrm{c}, \mathrm{d}}$ \\
\hline
\end{tabular}

Yields are expressed as protein recovery and phenolic compounds elimination for each procedure. Reported values for each protein product are means \pm standard deviation. In columns, means followed by the same letter are not significantly different $(p \geq 0.05)$ according to Fisher's test

* Values expressed on a dry basis

** The content of lipids, carbohydrates and fibers was calculated by difference

*** The content of proteins or phenolic compounds in the milled sunflower oil cake was considered $100 \%$. 


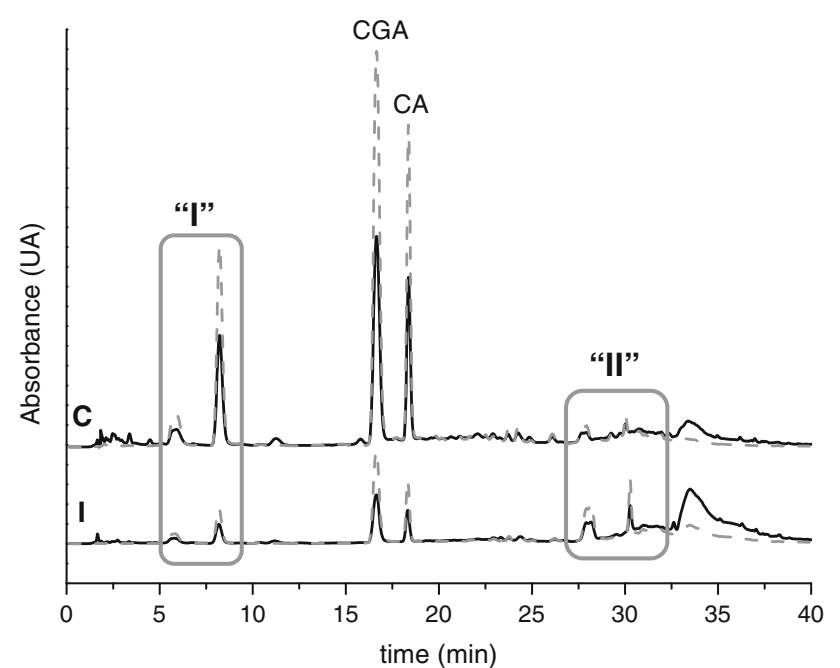

Fig. 1 RP-HPLC chromatogram of sunflower protein concentrates (C) and isolate $(I)$ at $280 \mathrm{~nm}$ (solid line) y $324 \mathrm{~nm}$ (dashed line)

eliminated with further water extraction steps and does not correlate with the final content of phenolic compounds. The intense color of these protein products should be taken into account when considering their potential applications.

Polypeptide Composition of Sunflower Protein

Concentrates and Isolates

To evaluate if the different extraction procedures used and/or isoelectric precipitation produces the removal of certain polypeptides, SDS-PAGE of the protein-enriched products was performed (Fig. 2). All the protein concentrates (Fig. 2a) and isolates (Fig. 2c), under non-reducing conditions contained mainly the $11 \mathrm{~S}$ globulins, with $\alpha-\beta$ subunits of molecular mass between 55 and $65 \mathrm{kDa}$. All the samples also contained aggregates of high molecular weight (HMWA, higher than $94 \mathrm{kDa}$ ), which could not enter the resolving gel. Under reducing conditions (Fig 2b, d), these aggregates disappeared completely from protein isolates, and were reduced from aqueous concentrates, suggesting that they were stabilized by disulfide bonds. Bands corresponding to $2 \mathrm{~S}$ albumins (Alb) (molecular weight between 14 and $18 \mathrm{kDa}$ ) were not observed either in $\mathrm{CW}$ and $\mathrm{CS}$ concentrates or in IW and IS isolates, possibly due to the fact that these proteins were highly soluble in water and were extracted during the aqueous extraction procedures performed to eliminate phenolic compounds. In the lanes corresponding to alcoholic products $(\mathrm{CE}, \mathrm{CM}$ and $\mathrm{CB})$ and to $\mathrm{CS}$, the presence of bands with molecular weight between 30-40 kDa and 20-30 kDa was noticeable (Fig. 2a, c). These correspond to acidic $(\alpha)$ and basic $(\beta)$ subunits, respectively. In SDS-PAGE patterns obtained under reducing conditions (Fig. 2b, d), all the protein products exhibited bands of molecular mass between $30-40 \mathrm{kDa}$ and 20-30 kDa, corresponding to acidic $(\alpha)$ and basic $(\beta)$ polypeptides, respectively. As mentioned above, only the concentrates presented high molecular weight soluble aggregates (HMWA) (which could not be resolved in the gel), albeit in lower concentration than under non-reducing conditions. The aggregates might be stabilized by covalent interactions because they are stable in the presence of SDS and resist thermal treatment.

\section{Protein Denaturation Degree of Sunflower Protein Concentrates and Isolates}

Concentrates and isolates had similar denaturation temperatures (Table 4) independent of whether aqueous extraction procedures were used to obtain them or not. In contrast, alcoholic extraction procedures generate concentrates with significantly higher denaturation temperatures $\left(\approx 110{ }^{\circ} \mathrm{C}\right)$ than those obtained using only aqueous solutions. These high denaturation temperatures can be a consequence of the stabilization effect produced by its high salt content (see Table 2). Consistent with this stabilization effect alcoholic concentrates had high denaturation enthalpies.

Table 3 Hunter Lab color parameters of the sunflower protein concentrates and isolates obtained

\begin{tabular}{|c|c|c|c|c|}
\hline \multirow[t]{2}{*}{ Sunflower protein products } & \multicolumn{4}{|c|}{ Hunter-Lab color parameters } \\
\hline & $L$ & $a$ & $b$ & $\Delta E$ \\
\hline $\mathrm{C}$ & $45.5 \pm 0.5^{\mathrm{b}}$ & $-4.6 \pm 0.1^{\mathrm{a}}$ & $7.4 \pm 0.2^{\mathrm{b}}$ & $52.3 \pm 0.4^{\mathrm{d}}$ \\
\hline $\mathrm{CW}$ & $49.0 \pm 0.6^{\mathrm{d}}$ & $1.7 \pm 0.1^{\mathrm{c}}$ & $10.8 \pm 0.2^{\mathrm{d}}$ & $49.2 \pm 0.5^{\mathrm{b}}$ \\
\hline $\mathrm{CS}$ & $53.8 \pm 0.4^{\mathrm{e}}$ & $4.4 \pm 0.1^{\mathrm{f}}$ & $16.2 \pm 0.3^{\mathrm{f}}$ & $46.0 \pm 0.4^{\mathrm{a}}$ \\
\hline I & $43.1 \pm 0.2^{\mathrm{a}}$ & $-3.6 \pm 0.1^{\mathrm{b}}$ & $4.3 \pm 0.1^{\mathrm{a}}$ & $54.4 \pm 0.2^{\mathrm{e}}$ \\
\hline IW & $46.4 \pm 0.5^{\mathrm{c}}$ & $1.8 \pm 0.1^{\mathrm{d}}$ & $9.4 \pm 0.3^{\mathrm{c}}$ & $51.5 \pm 0.5^{\mathrm{c}}$ \\
\hline IS & $49.4 \pm 0.3^{\mathrm{d}}$ & $4.0 \pm 0.1^{\mathrm{e}}$ & $11.8 \pm 0.2^{\mathrm{e}}$ & $49.1 \pm 0.2^{b}$ \\
\hline
\end{tabular}

Reported values for each protein product are means \pm standard deviation. In columns, means followed by the same letter are not significantly different $(p \geq 0.05)$ according to Fisher's test 
Fig. 2 SDS-PAGE

electrophoretic patterns

under non-reducing (a) or reducing conditions (b, $\beta$-mercaptoethanol added) of sunflower protein concentrates obtained at a laboratory scale. For both gels: $\mathrm{C}$ (lane 1), $\mathrm{CW}$ (lane 2), CS (lane 3), CE (lane 4), CM (lane 5), CB (lane 6), LMW standards (lane 7). SDSPAGE electrophoretic patterns under non-reducing (c) or reducing conditions (d) of sunflower protein isolates obtained at a laboratory scale. For both gels: LMW standards (lane 1), I (lane 2), IW (lane 3), IS (lane 4)

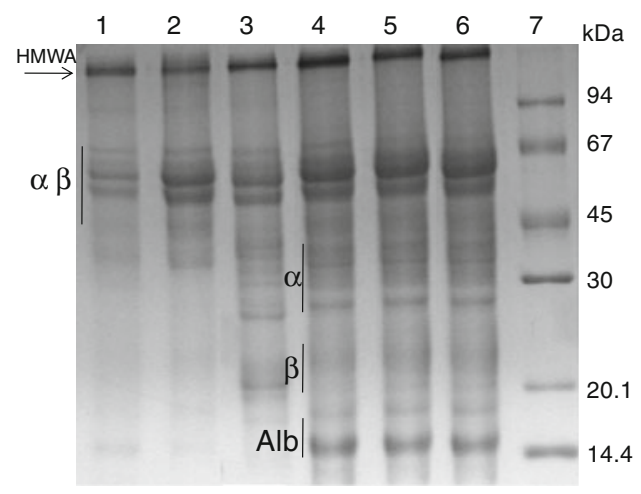

A

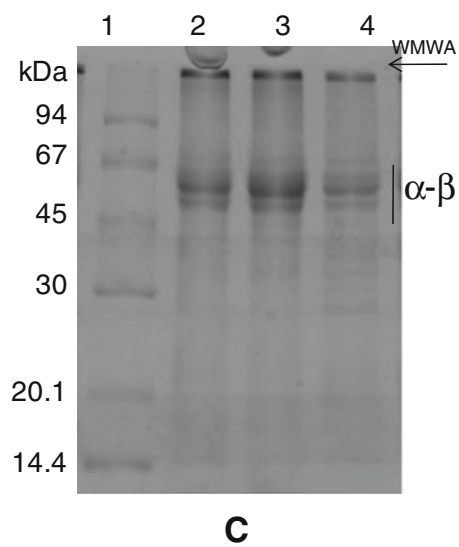

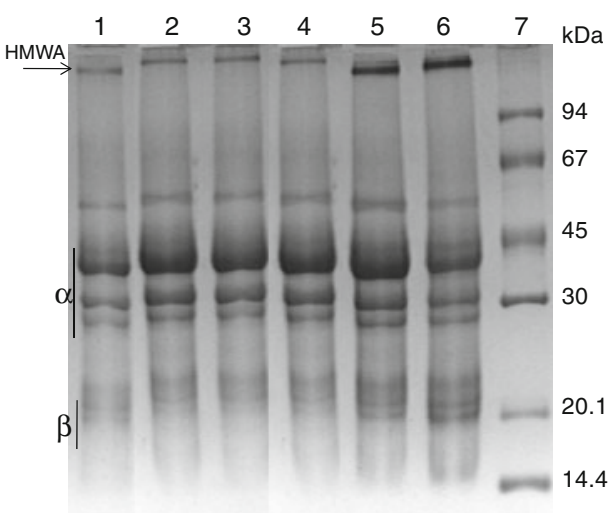

B

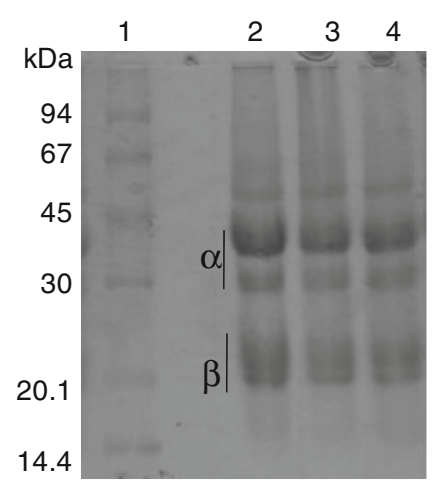

D
Table 4 Denaturation temperatures and enthalpies $\left(T_{\mathrm{d}}, \Delta H\right)$ of sunflower protein concentrates and isolates

\begin{tabular}{lcc}
\hline Sunflower protein products & \multicolumn{2}{l}{ DSC } \\
\cline { 2 - 3 } & \multicolumn{1}{l}{$T_{\mathrm{d}}\left({ }^{\circ} \mathrm{C}\right)$} & $\Delta H(\mathrm{~J} / \mathrm{g}$ protein $)$ \\
\hline $\mathrm{C}$ & $99.1 \pm 2.7^{\mathrm{a}}$ & $4.4 \pm 0.9^{\mathrm{a}}$ \\
$\mathrm{CW}$ & $99.6 \pm 1.5^{\mathrm{a}}$ & $11.2 \pm 1.5^{\mathrm{c}}$ \\
$\mathrm{CS}$ & $97.7 \pm 1.0^{\mathrm{a}}$ & $9.1 \pm 1.2^{\mathrm{b}, \mathrm{c}}$ \\
$\mathrm{CE}$ & $109.0 \pm 1.8^{\mathrm{b}}$ & $26.2 \pm 1.5^{\mathrm{d}}$ \\
$\mathrm{CM}$ & $110.7 \pm 0.7^{\mathrm{b}}$ & $25.4 \pm 0.6^{\mathrm{d}}$ \\
$\mathrm{CB}$ & $108.5 \pm 0.9^{\mathrm{b}}$ & $26.0 \pm 1.3^{\mathrm{d}}$ \\
$\mathrm{I}$ & $100.2 \pm 0.2^{\mathrm{a}}$ & $7.6 \pm 0.7^{\mathrm{b}}$ \\
IW & $99.6 \pm 0.1^{\mathrm{a}}$ & $8.2 \pm 0.5^{\mathrm{b}}$ \\
IS & $97.9 \pm 0.5^{\mathrm{a}}$ & $6.9 \pm 0.4^{\mathrm{b}}$ \\
\hline
\end{tabular}

Reported values for each protein product are means \pm standard deviation. In columns, means followed by the same letter are not significantly different $(p \geq 0.05)$ according to Fisher's test

Water Solubility and Surface Hydrophobicity of Sunflower Protein Concentrates and Isolates

Ho of the soluble protein fraction is a good parameter to predict uses as foaming agents and emulsifying agents [14]. These chemical properties were assessed in the proteins under study and their results are shown in Figs. 3 and 4, respectively. Alcoholic concentrates, especially those extracted with methanol and butanol, exhibited water solubility values significantly lower $(p<0.05)$ than aqueous concentrates and isolates (Fig. 3). The remaining products had high percentages (77-97\%) of protein solubility in water, with no significant differences $(p>0.05)$ among samples with different phenolic content. The CS concentrate exhibited the highest solubility $(97.3 \%)$, probably due to the fact that sulfite inhibits protein aggregation [26]. The solubility values are significantly higher than those reported by other authors for sunflower protein isolates obtained from laboratory flours (milling defatted sunflower seeds). For example, Rodríguez Patino et al. [27] reported 30\% water solubility at $\mathrm{pH} 8$, while Bau et al. [28] and Sripad et al. [29] reported values between 50 and $55 \%$.

Regarding Ho, it can be observed that the sample with highest phenolic content $(\mathrm{C})$ exhibited the lowest Ho, and that Ho increased with decreasing concentration of phenolic compounds (Fig. 4). In addition, Ho values of isolates were higher than those of the corresponding concentrates. It is possible that phenolic compounds promote protein aggregation, leading to a diminished Ho, although this molecular phenomenon did not affect sample solubility. In addition, alcoholic concentrates presented lower Ho than 
protein products with higher phenolic contents. In this case, the aggregation process could be promoted by the action of the extraction solvent.

To have a more realistic prediction of potential applications of the sunflower concentrates and isolates used in this work, a commercial soybean protein isolate (Supro 500E, The Solae Company, Brazil) was used as reference for the solubility and Ho assays. This soybean protein isolate, recommended as emulsifying and gelling additive, had Ho $\approx 75$ UA.ml $/ \mathrm{mg}$ which is lower than some of the sunflower enriched-protein products, e.g. CW, CS, I, IW and IS. Further studies are needed to confirm the possible applications of our sunflower protein products as food ingredients.

Antioxidant Properties of Sunflower Protein

Concentrates and Isolates

Nowadays it is recommended that people ingest antioxidants to prevent cancers and age related diseases [8]. The ABTS $^{+}$scavenging activity (Fig. 5) correlates with the content of soluble phenolic compounds $\left(r^{2}=0.9448\right)$. In every case, the isolates had a lower antioxidant capacity than their respective protein concentrates. These findings indicate that the presence of phenolic compounds (which cannot be removed because of their strong interaction with proteins, Fig. 1) confer antioxidant properties to the sunflower protein products.

\section{Conclusions}

Sunflower oil cake, a byproduct of the local oil industry, has a relatively high content of proteins making it an attractive product to be used as a raw material for the production of protein-rich products with high value. Although the procedures developed in this work were useful to produce sunflower protein concentrates and

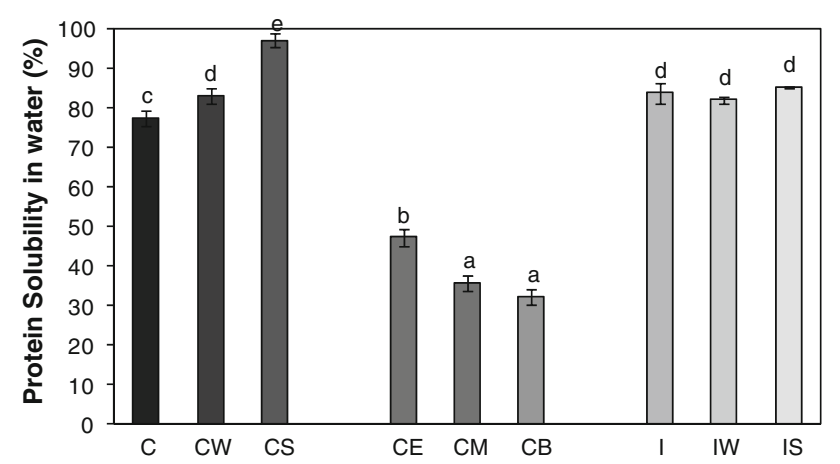

Fig. 3 Water solubility of proteins present in the sunflower protein concentrates and isolates obtained

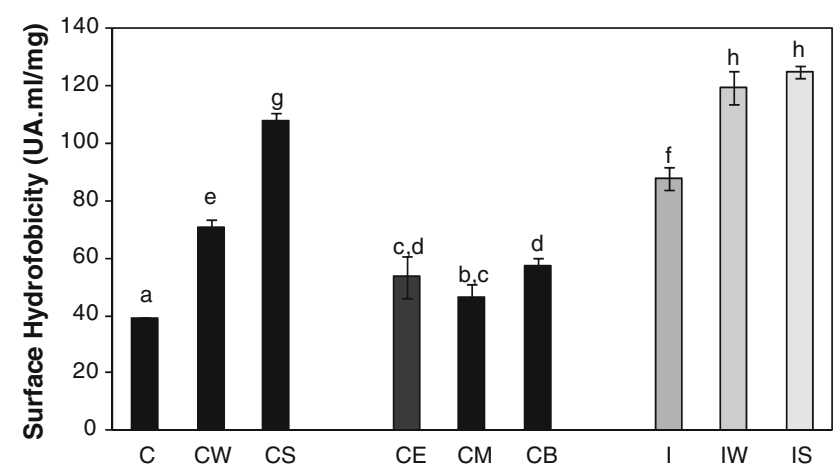

Fig. 4 Surface hydrophobicity of proteins present in the sunflower protein concentrates and isolates obtained

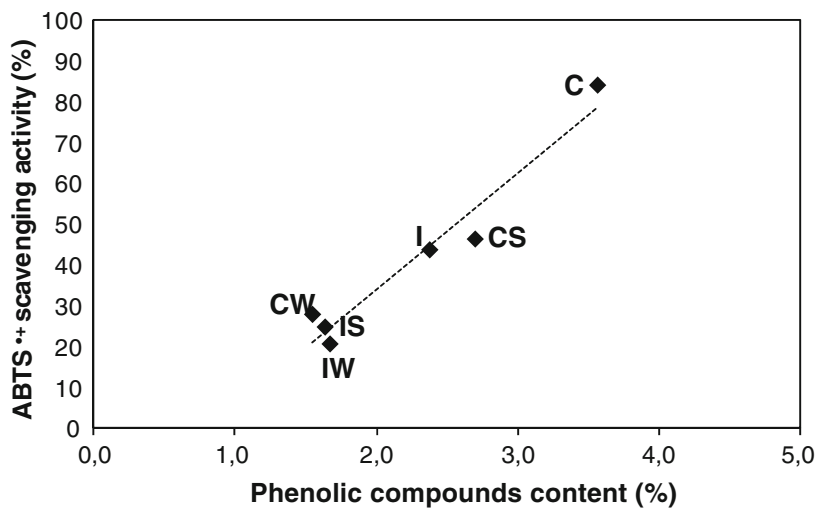

Fig. 5 Linear correlation between antioxidant capacity (ABTS ${ }^{+}$ scavenging activity) and content of phenolic compounds in sunflower protein concentrates and isolates

isolates with high water solubility and different physicochemical properties, the complete removal of phenolic compounds was not achieved because their association with proteins. The residual phenolic compounds endowed antioxidant properties to the protein products, without significantly affecting the water solubility. However, it induced a strong coloration to the products which could limit their potential applications.

Acknowledgments The authors wish to thank the National Research Council (CONICET, PIP 6094) and the National Agency of Scientific and Technological Support (SECyT, PICTO 13156 and PICT 35036) of Argentina for their financial support.

\section{References}

1. Moure A, Sineiro J, Domínguez H, Parajó JC (2006) Functionality of oilseed protein products: a review. Food Res Int 39:945-963

2. González-Pérez S, Vereijken JM (2008) Sunflower proteins: overview of their physicochemical, structural and functional properties. J Sci Food Agric 87:2172-2191 
3. Argentinean National Food Direction (SAGPyA) http://www. alimentosargentinos.gov.ar. Accessed June 2010

4. Prasad DT (1990) Proteins of the phenolic extracted sunflower meal: I. Simple method for removal of polyphenolic components and characteristics of salt soluble proteins. LWT 23:229-235

5. Pringent SVE, Gruppen H, Visser AJWG, van Koningsveld GA, De Jong GAH, Voragen AGJ (2003) Effects of non-covalent interactions with 5-O-caffeoyl quinic acid (Chlorogenic Acid) on the heat denaturation and solubility of globular proteins. J Agric Food Chem 51:5088-5095

6. González-Pérez S, Merck KB, Vereijken JM, Van Koningsveld GA, Gruppen H, Voragen AGJ (2002) Isolation and characterization of undenatured chlorogenic acid-free sunflower (Helianthus annuus) proteins. J Agric Food Chem 50:1713-1719

7. Rice-Evans CA, Miller NJ, Paganga G (1995) Structure-antioxidant activity relationships of flavonoids and phenolic acids. Free Radic Biol Med 20:933-956

8. Raskin I, Ribnicky DM, Komarnytsky S, Illic N, Poukev A, Bortsjuk N, Brinker A, Moreno D, Ripoll C, Yakoby N, O'Neil J, Cornwell T, Fridlender B (2002) Plants and human health in the twenty-first century. Trends Biotechnol 20:522-531

9. AOAC (1995) Official Methods of Analysis of AOAC International, 16th edn. AOAC International: Gaithersburg, MD

10. Moores RG, McDermott DL, Wood TR (1948) Determination of chlorogenic acid in coffee. Anal Chem 20:620-624

11. AOCS (1995) Official Methods and Recommended Practices of the AOCS, 5th edn. AOCS, Champaign

12. Molina MI, Petruccelli S, Añón MC (2004) Effect of pH and ionic strength modifications on thermal denaturation of the $11 \mathrm{~s}$ globulin of sunflower (Helianthus annuus). J Agric Food Chem 52:6023-6029

13. Laemmli UK (1970) Cleavage of structural proteins during the assembly of the head of bacteriophage T4. Nature 227:681-685

14. Petruccelli S, Añón MC (1994) Relationship between the method of obtention and the structural and functional properties of soy protein isolates. 2. Surface properties. J Agric Food Chem 42:2170-2176

15. Bradford MM (1976) A rapid and sensitive method for the quantification of microgram quantities of protein utilizing the principle of protein-dye binding. Anal Biochem 72:248-254

16. Kato A, Nakai S (1980) Hydrophobicity determined by a fluorescence probe method and its correlation with surface properties of proteins. Biochim Biophys Acta 624:13-20
17. Re R, Pellegrini N, Proteggente A, Pannala A, Yang M, RiceEvans CA (1999) Antioxidant activity applying an improved ABTS radical caution decolorization assay. Free Radic Biol Med 26:1231-1237

18. González RJ, Urquía MA (1975) Estudio del equilibrio práctico de extracción de proteínas a partir de harinas industriales de girasol. ITA UNL 1:75-80

19. Ayhllon-Meixueiro F, Vaca-Garcia C, Silvestre F (2000) Biodegradable films from isolate of sunflower (Helianthus annuus) proteins. J Agric Food Chem 48:3032-3036

20. Vioque J, Sánchez-Vioque R, Pedroche J, Yust MM, Millán F (2001) Obtención y aplicaciones de concentrados y aislados proteicos. Grasas y Aceites 52:127-131

21. Mendieta JR, Giudici MA, de la Canal L (2004) Occurrence of antimicrobial serin-proteinases in sunflower seeds. J Phytopathol 152:43-47

22. Damodaran S (1989) Interrelationship of molecular and functional properties of food proteins. Food proteins. AOCS Press, Champaign

23. Fujioka K, Shibamoto T (2008) Chlorogenic acid and caffeine contents in various commercial brewed coffees. Food Chem 106:217-221

24. Sosulski F (1979) Organoleptic and nutritional effects of phenolic compounds on oilseed protein products: a review. J Am Oil Chem Soc 56:711-715

25. Saeed M, Cheryan M (1988) Sunflower protein concentrates and isolates low in polyphenols and phytate. J Food Sci 53:1127-1143

26. Petruccelli S, Añón MC (1995) Partial reduction of soy protein isolate disulfide bonds. J Agric Food Chem 43:2001-2006

27. Rodríguez Patino JM, Caro AL, Rodríguez Niño MR, Mackie AR, Gunning AP, Morris VJ (2007) Some implications of nanoscience in food dispersion formulations containing phospholipids as emulsifiers. Food Chem 102:532-541

28. Bau HM, Mohtadi Nia DJ, Mejean L, Debry G (1983) Preparation of colorless sunflower protein products: effect of processing on physicochemical and nutritional properties. J Am Oil Chem Soc 60:1141-1148

29. Sripad G, Narasinga Rao MS (1987) Effect of methods to remove polyphenols from sunflower meal on the physicochemical properties of the proteins. J Agric Food Chem 35:962-967 